\title{
Borrelia Diversity and Co-infection with Other Tick Borne Pathogens in Ticks
}

OPEN ACCESS

Edited by: Linden $\mathrm{Hu}$,

Tufts University, USA

Reviewed by:

Tao Lin,

University of Texas McGovern Medical

School at Houston, USA Jon Blevins,

University of Arkansas for Medical

Sciences, USA

*Correspondence:

Gheorghe Savuta epirovet@yahoo.com

Muriel Vayssier-Taussat

muriel.vayssier@vet-alfort.fr

Received: 24 November 2016 Accepted: 31 January 2017

Published: 14 February 2017

Citation:

Raileanu C, Moutailler S, Pavel I, Porea D, Mihalca $A D$, Savuta $G$ and Vayssier-Taussat M (2017) Borrelia Diversity and Co-infection with Other

Tick Borne Pathogens in Ticks.

Front. Cell. Infect. Microbiol. 7:36.

doi: 10.3389/fcimb.2017.00036

\section{Cristian Raileanu ${ }^{1,2}$, Sara Moutailler ${ }^{1}$, Ionuț Pavel ${ }^{2}$, Daniela Porea ${ }^{2}$, Andrei D. Mihalca ${ }^{3}$, Gheorghe Savuta ${ }^{2 *}$ and Muriel Vayssier-Taussat ${ }^{1 *}$}

${ }^{1}$ INRA, UMR Bipar, INRA, Anses, ENVA, Maisons-Alfort, France, ${ }^{2}$ Department of Public Health, Faculty of Veterinary Medicine, University of Agricultural Sciences and Veterinary Medicine, Iași, Romania, ${ }^{3}$ Department of Parasitology and

Parasitic Diseases, University of Agricultural Sciences and Veterinary Medicine, Cluj-Napoca, Romania

Identifying Borrelia burgdorferi as the causative agent of Lyme disease in 1981 was a watershed moment in understanding the major impact that tick-borne zoonoses can have on public health worldwide, particularly in Europe and the USA. The medical importance of tick-borne diseases has long since been acknowledged, yet little is known regarding the occurrence of emerging tick-borne pathogens such as Borrelia spp., Anaplasma phagocytophilum, Rickettsia spp., Bartonella spp., "Candidatus Neoehrlichia mikurensis", and tick-borne encephalitis virus in questing ticks in Romania, a gateway into Europe. The objective of our study was to identify the infection and co-infection rates of different Borrelia genospecies along with other tick-borne pathogens in questing ticks collected from three geographically distinct areas in eastern Romania. We collected 557 questing adult and nymph ticks of three different species (534 Ixodes ricinus, 19 Haemaphysalis punctata, and 4 Dermacentor reticulatus) from three areas in Romania. We analyzed ticks individually for the presence of eight different Borrelia genospecies with high-throughput real-time PCR. Ticks with Borrelia were then tested for possible co-infections with A. phagocytophilum, Rickettsia spp., Bartonella spp., "Candidatus Neoehrlichia mikurensis", and tick-borne encephalitis virus. Borrelia spp. was detected in I. ricinus ticks from all sampling areas, with global prevalence rates of $25.8 \%$. All eight Borrelia genospecies were detected in I. ricinus ticks: Borrelia garinii (14.8\%), B. afzelii (8.8\%), B. valaisiana (5.1\%), B. lusitaniae (4.9\%), B. miyamotoi $(0.9 \%)$, B. burgdorferi s.s $(0.4 \%)$, and B. bissettii (0.2\%). Regarding pathogen co-infection $64.5 \%$ of infected I. ricinus were positive for more than one pathogen. Associations between different Borrelia genospecies were detected in $9.7 \%$ of ticks, and $6.9 \%$ of $I$. ricinus ticks tested positive for co-infection of Borrelia spp. with other tick-borne pathogens. The most common association was between B. garinii and B. afzelii (4.3\%), followed by B. garinii and B. lusitaniae (3.0\%). The most frequent dual co-infections were between Borrelia spp. and Rickettsia spp., (1.3\%), and between Borrelia spp. and "Candidatus Neoehrlichia mikurensis" (1.3\%). The diversity of tick-borne pathogens detected in this study and the frequency of co-infections should influence all infection risk evaluations following a tick bite.

Keywords: questing ticks, Borrelia, tick-borne pathogens, co-infection, Romania 


\section{INTRODUCTION}

In Europe, ticks are the most ecologically important vectors of pathogens that cause both human and animal diseases (de la Fuente et al., 2008). Ixodes ricinus ticks are the most common ticks in Europe, and are broadly distributed across the entire continent. They are capable of transmitting a wide variety of zoonotic pathogens, such as viruses, bacteria, protozoa, and even helminths (Egyed et al., 2012). I. ricinus is also the most common questing tick species in Romania, representing $86.9 \%$ of ticks, followed by Dermacentor marginatus (9.5\%), Haemaphysalis punctata (2.6\%), and D. reticulatus $(0.02 \%)$ (Mihalca et al., 2012a). Because I. ricinus feeds on a broad range of animals, this particular tick species transmits the widest variety of pathogens, including bacteria, parasites, and viruses. Amongst all I. ricinusborne diseases reported in Europe, Lyme disease caused by some genospecies of Borrelia burgdorferi sensu lato (s.l.), is by far the most prevalent, with an estimated 85,000 annual cases (Subramanian et al., 2012). B. burgdorferi s.l. group currently comprises over 20 genospecies, nine of which are circulating in Europe (Clark et al., 2014). Among these, five genospecies are human pathogens: B. afzelii, B. garinii, B. burgdorferi sensu stricto (s.s.), B. bavariensis, and B. spielmanii; three are suspected human pathogens: B. lusitaniae, B. valaisiana, and B. finlandensis; and one genospecies, $B$. bissettii, has no clinical relevance to humans. Another Borrelia genospecies, Borrelia miyamotoi, belongs to the relapsing fever group and is transmitted by the same Ixodes species that also transmits B. burgdorferi s.l.. In 2013 B. miyamotoi was identified as a human pathogen in Europe (Hovius et al., 2013). This bacterium has been also recently identified in Romania (Kalmár et al., 2016).

The same tick may be co-infected with different Borrelia genospecies (Cosson et al., 2014) and various other tick-borne pathogens, with the possibility of co-transmission to either humans or animals (Moutailler et al., 2016). These co-infections might have consequences in terms of pathogen co-transmission (Swanson et al., 2006; Nieto and Foley, 2009; Agoulon et al., 2012; Chowdri et al., 2013; Gugliotta et al., 2013; Horowitz et al., 2013; Hovius et al., 2013; Tijsse-Klasen et al., 2013; Cosson et al., 2014; Knapp and Rice, 2015) that may also have important implications and relevance to public health (Diuk-Wasser et al., 2016). Indeed, co-infection in humans and animals might enhance disease severity as has been reported for concurrent babesiosis and Lyme disease (Grunwaldt et al., 1983; Golightly et al., 1989), or may have consequences in term of treatment and diagnosis (DiukWasser et al., 2016).

The geopolitical location of Romania at the eastern border of the EU is strategically important from an epidemiological point of view. It represents a continual risk for emerging disease, not only in Romania, but also as a gateway into Europe. Only partial data has been collected on the prevalence of the Lyme disease agent or other tick-borne pathogens in eastern Romanian ticks and wildlife. However, it has been shown that Lyme disease is endemic in southern, eastern, and southeastern parts of Romania (Kalmar et al., 2013). From 2010, the Romanian National Centre for Surveillance and Control of Communicable Diseases has issued annual reports detailing the epidemiological situation of
Lyme disease in humans. An average of 340 confirmed human Lyme disease cases were recorded annually between 2010 and 2015 , with a mean incidence rate of 2.1 per 100,000 population, being situated at the lower level of the European incidence that ranges per country from less than one per 100,000 population to about 350 per 100,000 population (Rizzoli et al., 2011). Several studies have already reported the presence of Borrelia genospecies in questing ticks in Romania. Interestingly, these studies identified $B$. burgdorferi s.l. in $I$. ricinus ticks at a lower prevalence compared to the European average of $13.6 \%$ (Rauter and Hartung, 2005). A study involving over 12,000 questing ticks collected from 183 localities across all Romanian counties reported an overall B. burgdorferi s.l. prevalence of $1.4 \%$ (Kalmar et al., 2013). An alternate study of three southern and central Romanian counties recorded Lyme disease agent prevalence of up to $18.0 \%$ in unfed ticks (Coipan and Vladimirescu, 2011). Other studies in Romania have identified B. burgdorferi s.l. in I. ricinus ticks collected from different hosts such as lizards (Majláthová et al., 2008), horses (Ionita et al., 2013), hedgehogs (Dumitrache et al., 2013), and humans (Briciu et al., 2014). There are also reports of $B$. burgdorferi s.l. in tissues of wild mustelids (Gherman et al., 2012) and red foxes (Dumitrache et al., 2015). In these studies, the most commonly identified genospecies were $B$. afzelii, B. garinii, and B. burgdorferi s.s.

In Romania, as elsewhere in the world, limited work has been carried out on the occurrence of different Borrelia genospecies co-infections in questing ticks, including Borrelia with other tick-borne pathogens. Indeed, most studies have focused on the identification of single or a specific limited numbers of pathogens (Ionita et al., 2013, 2016; Kalmar et al., 2013; Matei et al., 2015; Kalmár et al., 2016), mainly due to technical constraints. Recently, we have implemented efficient highthroughput methods that enable broad-range co-detection of the most important known or putative tick-borne pathogens (Borrelia spp., Rickettsia spp., A. phagocytophilum, "Candidatus Neoehrlichia mikurensis”, Babesia spp., Bartonella spp. etc.) in individual tick samples (Michelet et al., 2014).

In the present study, our objective was to identify (co-) infection rates for different Borrelia genospecies along with other tick-borne pathogens in questing ticks collected from three sites in eastern Romania: One urban region dedicated to recreational activities and two forested areas.

\section{MATERIALS AND METHODS}

\section{Tick Sampling}

Questing ticks were collected from 19 sampling sites distributed across six counties, covering three geographically distinct areas of eastern Romania (Figure 1). Each area represented a distinct habitat: A forested area in the north-eastern part of the country (sampling area 1), suburban sites intended for recreational activities (sampling area 2), and sites located in the southern part of the country including a forested and an arid region (sampling area 3 ). Ticks were collected by the dragging method. Dragging was performed over 5 transects of $300 \mathrm{~m}$ at each location. Each transect was divided into 10 sub-transects which were separated by $20 \mathrm{~m}$, and the flag was examined after every 


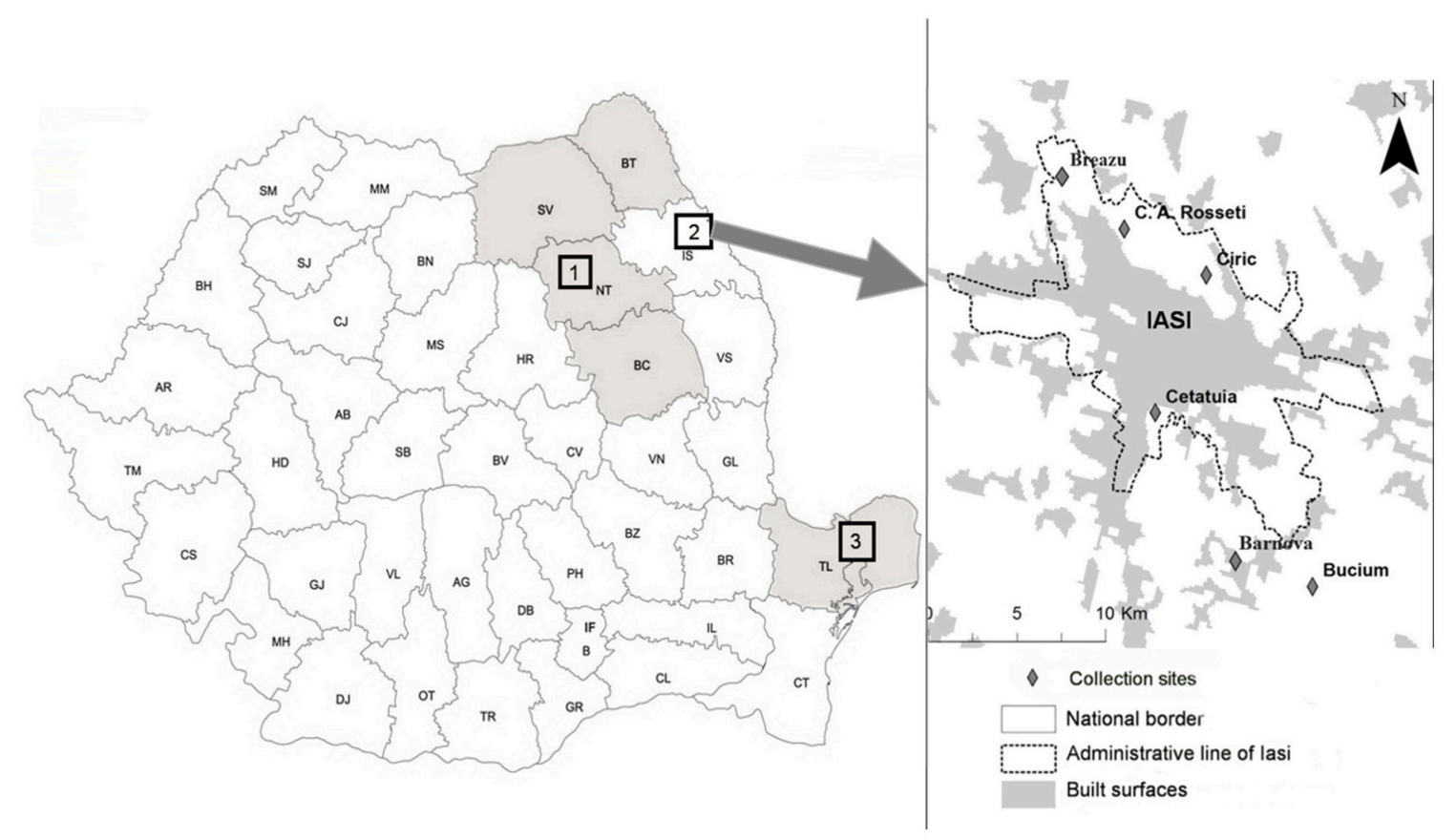

FIGURE 1 | Sampling areas in eastern Romania. Geographical areas were located in eastern Romania, comprising six counties across three distinct zones. Sampling areas 1 and 3 were mainly forested habitats, whereas sampling area 2 included six sites located in the vicinity of laşi recreational areas (C.A. Rosetti, Breazu, Ciric, Cetăţuia, Bârnova, and Bucium); Tick sampling took place from May 2013 until September 2014. (1)-Sampling area 1 covering four counties: SV, Suceava; BT, Botoşani; NT, Neamt; BC, Bacău.(2)-Sampling area 2: laşi-representing collection sites located in laşi recreational areas (Breazu, C.A. Rosseti, Ciric, Cetăţuia, Bârnova, Bucium). (3) - Sampling area 3 located in Tulcea county.

$10 \mathrm{~m}$ of dragging, at the end of each segment. The surface covered at each collection site was $\sim 1.5$ hectares. In sampling area 2 (Figure 1), monthly collection was performed at each site, from March until September 2014. Tick collection in areas 1 and 3 was performed only once at each site, between May 2013 and September 2014.

Sampling area 1 included six forested collection sites across four counties that were selected based on their proximity to rural settlements. (46.536747 N, 26.821123 E; $47.23221 \mathrm{~N}, 26.54634 \mathrm{E}$; 46.517207 N, 26.187067 E; 47.780000 N, 25.718600 E; 47.550000 N, 25.950000 E; and 47.779500 N, 26.516000 E) (Figure 1).

Sampling area 2 included six collection sites near Iaşi city recreational areas [Breazu (47.212044 N, 27.530304 E), C.A. Rosetti (47.204710 N, 27.556685 E), Ciric (47.178178 N, 27.609791 E), Cetăţuia (47.132564 N, 27.582936 E), Bârnova $(47.059598 \mathrm{~N}, 27.640815 \mathrm{E})$, and Bucium $(47.068330 \mathrm{~N}$, $27.664561 \mathrm{E})$ ] (Figure 1). The main criterion used for selection of collection sites was potential public exposure to vector ticks, and thus we included the major recreational sites around the city of Iaşi. Deciduous trees and meadows are the predominant vegetation at these sites (designated suburban forest) (Pavel et al., 2014).

Sampling area 3 included seven collection sites from Tulcea County $(45.269722 \mathrm{~N}, 28.459722 \mathrm{E} ; 45.215936 \mathrm{~N}, 28.415648 \mathrm{E}$; $45.26293 \mathrm{~N}, 28.16968 \mathrm{E} ; 44.891311 \mathrm{~N}, 28.717223 \mathrm{E} ; 44.873796$ $\mathrm{N}, 28.735763 \mathrm{E} ; 44.865767 \mathrm{~N}, 28.810092 \mathrm{E}$ and $44.86309 \mathrm{~N}$, $28.689242 \mathrm{E}$ ) that were located mostly in forested and arid zones
(Figure 1). This area has an arid or coastline type climate (Moise and Dumitru, 2012).

Tick species and developmental stages were identified under a stereomicroscope using standard morphological identification keys (Perez-Eid, 2007), then stored individually at $-80^{\circ} \mathrm{C}$.

\section{DNA and RNA Extraction}

Individual adult and nymph I. ricinus were lysed using 2.8 $\mathrm{mm}$ stainless steel beads in $300 \mu \mathrm{l}$ of culture cell medium (Dulbecco's Modified Eagle medium, Gibco by Life technologies, UK) complemented with $10 \%$ fetal calf serum as previously described (Vayssier-Taussat et al., 2012). Ticks were homogenized using Precellys 24 lyser/homogenizer (Bertin, France) at 5500 rpm for $20 \mathrm{~s}$. After homogenization, each tube was centrifuged at 1,500 rpm for $2 \mathrm{~min}$. DNA and RNA extraction was performed on $100 \mu \mathrm{L}$ aliquots using the Nucleospin Tissue kit or the Nucleospin RNA II kit (Macherey Nagel, Germany) according to the manufacturer's instructions. Purified DNA and RNA was eluted into $50 \mu \mathrm{L}$ elution buffer, RNase-free water respectively.

\section{Detection of Borrelia Genospecies DNA in Questing I. ricinus}

The BioMark ${ }^{\mathrm{TM}}$ real-time PCR system (Fluidigm, USA) was used for high-throughput microfluidic real-time PCR for the detection of the genus Borrelia: Seven genospecies belonging to the Lyme disease spirochete group, B. burgdorferi s.l. (B. burgdorferi s.s., $B$. afzelii, B. garinii, B. spielmanii, B. valaisiana, B. lusitaniae, and 
B. bissettii) and one genospecies from the recurrent fever group (B. miyamotoi) (Table 1). A DNA pre-amplification step was performed in a final volume of $5 \mu \mathrm{L}$ containing $2.5 \mu \mathrm{L}$ TaqMan PreAmp Master Mix (2X), $1.2 \mu \mathrm{L}$ of the pooled primer mix $(0.2 \mathrm{X}$ mix containing specific primer pairs for each of the eight Borrelia genospecies analyzed) and $1.3 \mu \mathrm{L}$ of tick DNA, with one cycle at $95^{\circ} \mathrm{C}$ for $10 \mathrm{~min}, 14$ cycles at $95^{\circ} \mathrm{C}$ for $15 \mathrm{~s}$ and $4 \mathrm{~min}$ at $60^{\circ} \mathrm{C}$. Following pre-amplification, qPCRs were performed using FAM- and black hole quencher (BHQ1)-labeled TaqMan probes (Michelet et al., 2014) with TaqMan Gene Expression Master Mix in accordance with manufacturer's instructions (Applied Biosystems, France). Thermal cycling conditions were as follows: $95^{\circ} \mathrm{C}$ for $5 \mathrm{~min}, 45 \mathrm{cycles}$ at $95^{\circ} \mathrm{C}$ for $10 \mathrm{~s}, 60^{\circ} \mathrm{C}$ for $15 \mathrm{~s}$, and $40^{\circ} \mathrm{C}$ for $10 \mathrm{~s}$. Data were acquired on the BioMark ${ }^{\mathrm{TM}}$ real-time PCR system and analyzed using the Fluidigm real-time PCR Analysis software to obtain crossing point (CP) values. Assays were performed in duplicate and two negative water controls were included per analysis and none of them were found positive after amplification. I. ricinus DNA served to confirm the tested tick species and as a DNA extraction control (Michelet et al., 2014). Moreover, to determine if factors present in the samples could inhibit PCR (false negative results), E. coli strain EDC933 DNA was added to each sample as internal inhibition control (Michelet et al., 2014). E. coli and I. ricinus DNA were amplified in all samples confirming the absence of false negative results.

\section{Detection of Co-infections with Other Tick-Borne Pathogens}

Bartonella spp. and Rickettsia spp.: All DNA samples positive for Borrelia genospecies were screened for the presence of Bartonella spp. and Rickettsia spp. via PCR. Detection was carried out using specific primers targeting the gltA gene of both Bartonella spp. (Norman et al., 1995) and Rickettsia spp. (Table 1) (Regnery et al., 1991). PCR products were amplified using the Thermo Scientific Phusion High-Fidelity PCR Kit (Thermo Scientific, USA). Each reaction was carried out in a $20 \mu \mathrm{l}$ reaction volume containing $5 \mu \mathrm{l}$ tick DNA, $4 \mu \mathrm{l} 5 \mathrm{X}$ PCR buffer, $200 \mu \mathrm{M}$ of each dNTP, $0.5 \mu \mathrm{M}$ of each primer, and $0.4 \mathrm{U}$ phusion DNA polymerase. Thermal conditions were $98^{\circ} \mathrm{C}$ for $30 \mathrm{~s}$, followed by 35 cycles at $98^{\circ} \mathrm{C}$ for $10 \mathrm{~s}, 52^{\circ} \mathrm{C}$ (for Bartonella spp.) or $56^{\circ} \mathrm{C}$ (for Rickettsia spp.) for $30 \mathrm{~s}$, and $72^{\circ} \mathrm{C}$ for $30 \mathrm{~s}$, with a final elongation at $72^{\circ} \mathrm{C}$ for $10 \mathrm{~min}$. The 380-400 bp Bartonella-specific fragment and the 381 bp Rickettsia-specific fragment were sequenced by Eurofins MWG Operon (Ebesberg, Germany). Sequences were assembled using BioEdit software (Hall, 1999), and compared to the NCBI database for species identification.

A. phagocytophilum, "C. N. mikurensis": Real-time PCR assays were performed using primers and probes targeting the $m s p 2$ gene for $A$. phagocytophilum, and the groEL gene for " $C$. $\mathrm{N}$. mikurensis" (Table 1) (Michelet et al., 2014). All fluorogenic probes were synthesized with a 6-carboxy-fluorescein (FAM) reporter molecule attached to the $5^{\prime}$ end and a Black Hole Quencher 1 (BHQ1) at the $3^{\prime}$ terminus. Real-time Taqman PCR assays were performed in a final volume of $12 \mu \mathrm{l}$ using the LightCycler ${ }^{\circledR} 480$ Probe Master mix (Roche Applied Science, Germany) at $1 \mathrm{X}$ final concentration, with primers and probes at $200 \mathrm{nM}$, and $2 \mu \mathrm{l}$ DNA. Negative (water) and positive controls were included with each run. Thermal cycling conditions were as follows: $95^{\circ} \mathrm{C}$ for $5 \mathrm{~min}, 45$ cycles at $95^{\circ} \mathrm{C}$ for $10 \mathrm{~s}$, then $60^{\circ} \mathrm{C}$ for $15 \mathrm{~s}$, with a final cooling step at $40^{\circ} \mathrm{C}$ for $10 \mathrm{~s}$.

TBEV: RNA samples were screened for tick-borne encephalitis virus (TBEV) by rRT-PCR targeting a $3^{\prime}$ non-coding region of the TBEV genome with specific primers and probes (Table 1) (Schwaiger and Cassinotti, 2003). rRT-PCR Taqman assays were performed in a final volume of $20 \mu \mathrm{l}$ using the LightCycler ${ }^{\circledR}$ 480 RNA Master Hydrolysis Probes master mix (Roche Applied Science, Germany) at $1 \mathrm{X}$ final concentration, with $0.5 \mu \mathrm{M}$ specific primers and $0.25 \mu \mathrm{M}$ probes, $3.25 \mathrm{mM}$ manganese acetate $\left[\mathrm{Mn}(\mathrm{OAc})_{2}\right]$ and $2 \mu \mathrm{l}$ RNA. Positive and negative (water) controls were included in each run. rRT-PCR thermal cycling conditions were as follows: $63^{\circ} \mathrm{C}$ for $3 \mathrm{~min}, 95^{\circ} \mathrm{C}$ for $30 \mathrm{~s}, 45$ cycles at $95^{\circ} \mathrm{C}$ for $10 \mathrm{~s}$, then $60^{\circ} \mathrm{C}$ for $30 \mathrm{~s}$, followed by cooling at $40^{\circ} \mathrm{C}$ for $10 \mathrm{~s}$. Positive samples were used for one-step RTPCR and nested PCR targeting the non-structural protein gene NS5 (Puchhammer-Stockl et al., 1995). Positive RNA samples were reverse transcribed using Titan One Tube RT-PCR Systems (Roche Applied Science, Germany) in a $50 \mu \mathrm{l}$ reaction volume containing $10 \mu \mathrm{l}$ tick RNA, $10 \mu \mathrm{l} 5 \mathrm{X}$ RT-PCR buffer, $200 \mu \mathrm{M}$ of each dNTP, $0.4 \mu \mathrm{M}$ of each primer, $1 \mu \mathrm{l}$ enzyme mix and 500 $\mu \mathrm{M}$ dithiothreitol (DTT). Thermal cycling conditions were $50^{\circ} \mathrm{C}$ for $30 \mathrm{~min}, 95^{\circ} \mathrm{C}$ for $3 \mathrm{~min}$, followed by 35 cycles at $95^{\circ} \mathrm{C}$ for 30 $\mathrm{s}, 40^{\circ} \mathrm{C}$ for $30 \mathrm{~s}$, and $72^{\circ} \mathrm{C}$ for $30 \mathrm{~s}$, with a final step at $72^{\circ} \mathrm{C}$ for 5 min. Nested PCR was performed using the Thermo Scientific Phusion High-Fidelity PCR Kit (Thermo Scientific, USA). PCRs were carried out in a $50 \mu \mathrm{l}$ reaction volume containing $5 \mu \mathrm{l}$ tick cDNA, $10 \mu 15 \mathrm{X}$ PCR buffer, $200 \mu \mathrm{M}$ of each dNTP, 0.5 $\mu \mathrm{M}$ of each internal primer, and $1 \mathrm{U}$ Phusion DNA polymerase. Thermal conditions were $98^{\circ} \mathrm{C}$ for $30 \mathrm{~s}$, followed by 35 cycles at $98^{\circ} \mathrm{C}$ for $10 \mathrm{~s}, 53 \mathrm{C}$ for $30 \mathrm{~s}$, and $72^{\circ} \mathrm{C}$ for $60 \mathrm{~s}$, and a final elongation at $72^{\circ} \mathrm{C}$ for $10 \mathrm{~min}$.

\section{Statistical Analysis}

The data were processed using IBM SPSS ${ }^{\circledR}$ Statistics version 21 (IBM $^{\circledR}$ Corporation, Chicago, IL, USA) software. One-way analysis of variance (ANOVA) tests (Bonferroni post-hoc test) were performed on tick infection rates for geographic groups. Prevalence rates were compared between tick developmental stages using independent sample $T$-tests. In cases of statistical significance, $p$-values are presented in parentheses. Differences were considered statistically significant when $p<0.05$.

\section{RESULTS}

\section{Tick Collection}

Using the dragging protocol, we collected 557 ticks belonging to three different species: I. ricinus (from all sampling areas), Dermacentor reticulatus (only from sampling area 2), and H. punctata (from sampling areas 2 and 3). I. ricinus ticks represented $95.9 \%(534 / 557)$ of the collected ticks, with 77 adult ticks and 457 nymphs, D. reticulatus represented $0.7 \%(4 / 557)$ of collected ticks with four adults, and $H$. punctata represented $3.4 \%$ $(19 / 557)$ of collected ticks with three adults and 16 nymphs. 
TABLE 1 | Primer sets for pathogen DNA amplification and sequencing in ticks.

\begin{tabular}{|c|c|c|c|c|c|}
\hline Pathogen & Target gene & Primers & Nucleotide sequence $\left(5^{\prime}-3^{\prime}\right)$ & $\begin{array}{l}\text { Amplicon } \\
\text { size (bp) }\end{array}$ & References \\
\hline Bartonella spp. & gltA & $\begin{array}{l}\text { bart781 } \\
\text { bart1137 }\end{array}$ & $\begin{array}{l}\text { GGGGACCAGCTCATGGTGG } \\
\text { AATGCAAAAAGAACAGTAAACA }\end{array}$ & $380-400$ & Norman et al., 1995 \\
\hline Rickettsia spp. & gltA & $\begin{array}{l}\text { Rsfg877 } \\
\text { Rsfg1258 }\end{array}$ & $\begin{array}{l}\text { GGGGGCCTGCTCACGGCGG } \\
\text { ATTGCAAAAAGTACAGTGAACA }\end{array}$ & 381 & Regnery et al., 1991 \\
\hline Borrelia spp. & $23 S$ rRNA & $\begin{array}{l}\text { Bo_bu_sl_23S_F } \\
\text { Bo_bu_sl_23S_R } \\
\text { Bo_bu_sl_23S_P }\end{array}$ & $\begin{array}{l}\text { GAGTCTTAAAAGGGCGATTTAGT } \\
\text { CTTCAGCCTGGCCATAAATAG } \\
\text { AGATGTGGTAGACCCGAAGCCGAGT }\end{array}$ & 73 & Michelet et al., 2014 \\
\hline Borrelia burgdorferi, sensu stricto & rpoB & $\begin{array}{l}\text { Bo_bu_rpoB_F } \\
\text { Bo_bu_rpoB_R, } \\
\text { Bo_bu_rpoB_P }\end{array}$ & $\begin{array}{l}\text { GCTTACTCACAAAAGGCGTCTT } \\
\text { GCACATCTCTTACTTCAAATCCT } \\
\text { AATGCTCTTGGACCAGGAGGACTTCA }\end{array}$ & 83 & Michelet et al., 2014 \\
\hline Borrelia garinii & rpoB & $\begin{array}{l}\text { Bo_ga_rpoB_F } \\
\text { Bo_ga_rpoB_R } \\
\text { Bo_ga_rpoB_P }\end{array}$ & $\begin{array}{l}\text { TGGCCGAACTTACCCACAAAA } \\
\text { ACATCTCTTACTTCAAATCCTGC } \\
\text { TCTATCTCTTGAAAGTCCCCCTGGTCC }\end{array}$ & 88 & Michelet et al., 2014 \\
\hline Borrelia Iusitaniae & rpoB & $\begin{array}{l}\text { Bo_lus_rpoB_F } \\
\text { Bo_lus_rpoB_R } \\
\text { Bo_lus_rpoB_P }\end{array}$ & $\begin{array}{l}\text { CGAACTTACTCATAAAAGGCGTC } \\
\text { TGGACGTCTCTTACTTCAAATCC } \\
\text { TTAATGCTCTCGGGCCTGGGGGACT }\end{array}$ & 87 & Michelet et al., 2014 \\
\hline Borrelia spielmanii & fla & $\begin{array}{l}\text { Bo_spi_fla_F } \\
\text { Bo_spi_fla_R } \\
\text { Bo_spi_fla_P }\end{array}$ & $\begin{array}{l}\text { ATCTATTICTGGTGAGGGAGC } \\
\text { TCCTTCTTGTTGAGCACCTTC } \\
\text { TTGAACAGGCGCAGTCTGAGCAGCTT }\end{array}$ & 71 & Michelet et al., 2014 \\
\hline Borrelia bissettii & rpoB & $\begin{array}{l}\text { Bo_bi_rpoB_F } \\
\text { Bo_bi_rpoB_R } \\
\text { Bo_bi_rpoB_P }\end{array}$ & $\begin{array}{l}\text { GCAACCAGTCAGCTTTCACAG } \\
\text { CAAATCCTGCCCTATCCCTTG } \\
\text { AAAGTCCTCCCGGCCCAAGAGCATTAA }\end{array}$ & 118 & Michelet et al., 2014 \\
\hline \multirow[t]{3}{*}{ TBEV } & $\begin{array}{l}3^{\prime} \text { non-coding } \\
\text { region }\end{array}$ & $\begin{array}{l}\text { F-TBE 1 R-TBE } \\
1 \\
\text { TBE-Probe-WT }\end{array}$ & $\begin{array}{l}\text { GGGCGGTTCTTGTTCTCC } \\
\text { ACACATCACCTCCTTGTCAGACT } \\
\text { TGAGCCACCATCACCCAGACACA }\end{array}$ & 67 & $\begin{array}{l}\text { Schwaiger and } \\
\text { Cassinotti, } 2003\end{array}$ \\
\hline & $\begin{array}{l}\text { non-structural } \\
\text { protein NS5 }\end{array}$ & $\begin{array}{l}\text { Outer primers: } \\
\text { FSM-1 } \\
\text { FSM-2 }\end{array}$ & $\begin{array}{l}\text { GAGGCTGAACAACTGCACGA } \\
\text { GAACACGTCCATTCCTGATCT }\end{array}$ & 357 & $\begin{array}{l}\text { Schwaiger and } \\
\text { Cassinotti, } 2003\end{array}$ \\
\hline & $\begin{array}{l}\text { non-structural } \\
\text { protein NS5 }\end{array}$ & $\begin{array}{l}\text { Inner primers: } \\
\text { FSM-li } \\
\text { FSM-2i }\end{array}$ & $\begin{array}{l}\text { ACGGAACGTGACAAGGCTAG } \\
\text { GCTTGTTACCATCTTGGAG }\end{array}$ & 251 & $\begin{array}{l}\text { Schwaiger and } \\
\text { Cassinotti, } 2003\end{array}$ \\
\hline
\end{tabular}

\section{Borrelia Genospecies Detected in Ticks}

Borrelia spp. DNA was identified in 138/534 (25.8\%) of I. ricinus ticks collected from all sampling sites, in none of the four $D$. reticulatus ticks, and in 1/19 (5.3\%) $\mathrm{H}$. punctata collected from area 2. Borrelia genospecies found in $H$. punctata was identified as B. miyamotoi. The B. miyamotoi-positive $H$. punctata was not co-infected with other screened tick-borne pathogens.

In I. ricinus ticks, Borrelia spp. infection rates were not significantly different between adults $(26.0 \%$; $20 / 77)$ and nymphs
(25.8\%; 118/457) ( $p>0.05)$. Borrelia spp. prevalence was significantly higher in I. ricinus ticks collected from area 3 in the southernmost sector of eastern Romania, than in ticks from areas $1(p<0.05)$ and $2(p<0.05)(40.0 \%$ vs. $25.0 \%$ or $25.0 \%$ in adults, and $40.0 \%$ vs. $22.0 \%$ or $16.7 \%$ in nymphs).

Eight genospecies of Borrelia were identified: B. garinii, $B$. afzelii, B. valaisiana, B. lusitaniae, B. spielmanii, B. burgdorferi s.s., B. bissettii, and B. miyamotoi. The mean infection rate was $14.8 \%$ for B. garinii $(16.9 \%$ of the adults and $14.4 \%$ of the 
nymphs), $8.8 \%$ for B. afzelii (7.8\% of adults and $9.0 \%$ of nymphs), $5.1 \%$ for B. valaisiana (5.2\% of adults and $5.0 \%$ of nymphs), $4.9 \%$ for $B$. lusitaniae (5.2\% of adults and $4.8 \%$ of nymphs), $1.1 \%$ for B. spielmanii (1.3\% of adults and $1.1 \%$ of nymphs), $0.9 \%$ for $B$. miyamotoi ( $1.3 \%$ of adults and $0.9 \%$ of nymphs), $0.4 \%$ for $B$. burgdorferi s.s. (0.4\% of nymphs), and $0.2 \%$ for B. bissettii $(0.2 \%$ of nymphs).

The infection rates of different Borrelia genospecies in $I$. ricinus ticks according to collection site is shown in Table 2. Ticks collected from area 1 were more frequently infected with $B$. afzelii but did not register statistical significance. Ticks from area 3 were more frequently infected with $B$. garinii, with a statistically significant difference only when compared to B. garinii infection rates in area $2(p<0.05)$. B. valaisiana also demonstrated a high infection rate in area 3 , which was statistically different to the prevalence rate obtained in area $2(p<0.05)$. B. lusitaniae prevalence was significantly higher in area 3 than in areas 1 and 2 $(p<0.05)$. B. spielmanii was detected in areas 2 and 3 with similar infection rates; $B$. burgdorferi s.s. was only detected in areas 1 and 2 , and $B$. bissettii was only detected in area 1 . Relapsing fever agent B. miyamotoi was only detected in areas 1 and 2 (see Table 2).

\section{Co-infections in Ixodes ricinus}

Co-infections were identified in $16.7 \%$ I. ricinus ticks (89/534), which accounted for $64.5 \%(89 / 138)$ of all infected ticks. Coinfection prevalence was $14.3 \%(11 / 77)$ in adults and $17.1 \%$ (78/457) in nymphs. Co-infection rates were significantly higher in area $3(27.7 \% ; 47 / 170)$ than in areas 1 and 2 (14.9\%; 10/67 and $10.8 \% ; 32 / 297$, respectively) resulting in a statistically significant difference only when compared to area $2(p<0.05)$.

\section{Co-infection between Borrelia Genospecies}

The overall prevalence of $B$. burgdorferi s.l. genospecies coinfection was $9.7 \%(52 / 534 ; 9.1 \%$ of adults and $9.8 \%$ of nymphs). Forty-five I. ricinus ticks were co-infected with two B. burgdorferi s.l. genospecies. The most frequent Borrelia genospecies association was between $B$. garinii and $B$. afzelii (23/534; $4.3 \%)$, followed by B. garinii and B. lusitaniae (16/534; $3.0 \%)$. Triple B. burgdorferi s.l. genospecies co-infection was identified in seven $I$. ricinus ticks, four of which were infected with B. garinii, B. afzelii, and B. valaisiana (Table 3). Co-infection rates between Borrelia genospecies were significantly higher in area 3 [15.3\% (26/170; $40.0 \%$ adults and $14.5 \%$ nymphs)] than in areas 1 and 2 [8.9\% (6/67; $10.1 \%$ nymphs) and 6.7\% (20/297; $7.8 \%$ adults and $6.4 \%$ nymphs)], respectively $(p<0.05)$.

\section{Co-infection between Borrelia Genospecies and Other Tick-Borne Pathogens}

Co-infections of Borrelia genospecies with other tick-borne pathogens occurred in $6.9 \%$ of all collected $I$. ricinus ticks (37/534; $5.2 \%$ of adults and $7.2 \%$ of nymphs), and were observed in ticks from all three sampling areas as follows: $6.0 \%$ of ticks from area 1 (4/67; $25.0 \%$ of adults and $3.4 \%$ of nymphs), $4.0 \%$ of ticks from area $2(12 / 297 ; 3.1 \%$ of adults and $4.3 \%$ of nymphs), and $12.4 \%$ of ticks from area 3 (21/170; $12.7 \%$ of nymphs).

Dual co-infection between one Borrelia genospecies and another pathogen occurred in 20 I. ricinus ticks (20/534; 3.7\%). The most frequent co-infection was between Borrelia spp. and Rickettsia spp., and between Borrelia spp. and "C. N. mikurensis", where each association was detected in seven different $I$. ricinus ticks. Five samples tested positive for Borrelia spp. and Bartonella spp., and one tick was co-infected with Borrelia spp. and $A$. phagocytophilum.

Association of two Borrelia genospecies with another pathogen genus was detected in 12 ticks $(12 / 534 ; 2.4 \%)$, of which nine ticks tested positive for co-infection with two Borrelia genospecies and one Rickettsia spp. We detected two samples infected with Borrelia genospecies and "C. N. mikurensis", and

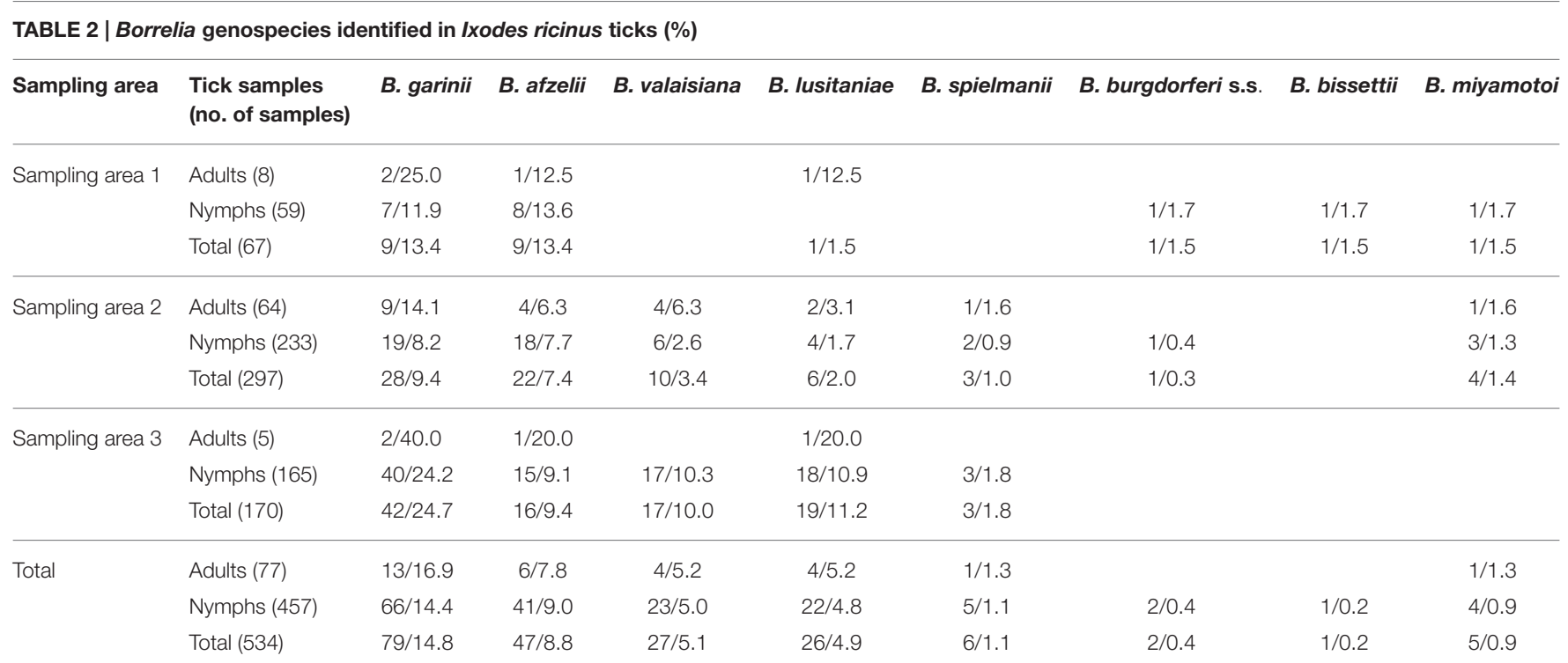


one sample co-infected with two Borrelia genospecies and $A$. phagocytophilum.

We also recorded four $(4 / 534 ; 0.7 \%)$ ticks infected with one Borrelia genospecies and two other pathogen genera: Three ticks positive for the association of Borrelia spp. + Rickettsia spp. + "C. N. mikurensis", and one tick positive for Borrelia spp., Rickettsia spp., and Bartonella spp. One tick was positive for three different Borrelia genospecies (B. garinii, B. afzelii, B. lusitaniae), and " $C$. N. mikurensis" (Table 3).

We did not identify co-infections between Borrelia genospecies with tick-borne encephalitis virus.

\section{DISCUSSION}

Using a powerful high-throughput tool we performed a comprehensive overview of the epidemiological status of Lyme spirochetes circulating and co-circulating with other important tick-borne pathogens in eastern Romanian ticks. The most important findings were: (1) the identification of seven different genospecies of the Lyme spirochete group-including B. miyamotoi-with an overall high Borrelia prevalence rate (25.8\% of ticks infected); (2) the frequency of co-infection: Among Borrelia-infected ticks, $64.5 \%$ were co-infected; (3) the unexpected high infection and co-infection rates of ticks collected from the Danube Delta biosphere (area 3). Together, these results may have important implications in terms of public health issues in a country where Lyme disease surveillance has only been implemented since 2009.

In our study, the overall Borrelia prevalence rate across all sampling areas $(25.8 \%)$, was much higher than compared to previous studies of this Lyme disease agent in questing I. ricinus ticks from Romania that reported prevalences ranging from 3.8 to 18\% (Coipan and Vladimirescu, 2011; Kalmar et al., 2013). This result is likely due to high sensitivity of our techniques which combines pathogen DNA pre-amplification steps with specific quantitative amplification of target pathogen DNA.

\section{Different Borrelia Genospecies Identified}

B. garinii and B. afzelii were the most abundant Borrelia genospecies in our study, as has been previously reported in Romanian ticks (Coipan and Vladimirescu, 2010, 2011; Kalmar et al., 2013; Briciu et al., 2014). Several other studies have shown that certain Borrelia genospecies have preferred reservoir hosts; $B$. garinii is mostly associated with birds, whereas $B$. afzelii genospecies are predominantly isolated from mediumsized and small mammals, especially rodents (Dubska et al., 2009; Rizzoli et al., 2011; Mannelli et al., 2012). Hence Borrelia genospecies prevalence in specific areas is thus closely related to the abundance of competent reservoir hosts (Rizzoli et al., 2011). The high prevalence of $B$. garinii might be due to the increased density of bird-based enzootic cycles in eastern Romania, especially in area 3 (Danube Delta region), which represents an important stopover site for over 300 different avian species migrating between northern Eurasia and Africa (Sándor et al., 2014). Northward, near Iaşi, 129 bird species have been identified (Gache, 2016) including song thrushes (Turdus philomelos) and blackbirds (T. merula), reported to be the principle B. garinii reservoir in central Europe (Taragel'ova et al., 2008). B. afzelii was the second most prevalent genospecies, and is predominantly cycled throughout Europe via rodent species (Apodemus sylvaticus, A. agrarius, A. flavicollis, and Myodes glareolus), known common tick hosts (Mihalca et al., 2012b). The 32 species of wild rodents found in Romania (Mihalca et al., 2012 b) emphasize the significant biodiversity and availability of putative $B$. afzelii reservoir hosts.

Borrelia valaisiana and $B$. lusitaniae had similar infection rates in questing ticks, and B. lusitaniae was detected at all three sampling areas. The pathogenicity of these genospecies is still uncertain, even though there is evidence of their presence in skin biopsies and cerebrospinal fluid of patients with Lyme disease (Diza et al., 2004; Rauter and Hartung, 2005). Similarly to $B$. garinii, B. valaisiana is more commonly identified in birds, while $B$. lusitaniae is mainly associated with lizards (Rizzoli et al., 2011; Mannelli et al., 2012). We report higher B. valaisiana and $B$. lusitaniae infection rates in Romania compared to previous studies (de la Fuente et al., 2008; Kalmar et al., 2013), which may be a result of high reservoir host density. In Romania, lizards are commonly found, the green lizard (Lacerta viridis) and sand lizard (Lacerta agilis) are both widely distributed throughout our study areas (Cogalniceanu et al., 2013). The role of these host species in the transmission cycle of $B$. lusitaniae has been studied in Slovakia, Poland, and Romania (Majlathova et al., 2006; Majláthová et al., 2008), thus it is likely that their presence induces favorable conditions for $B$. lusitaniae persistence in eastern Romania.

We also detected three other $B$. burgdorferi s.l. group genospecies at low levels: B. burgdorferi s.s., B. spielmanii, and $B$. bissettii. B. burgdorferi s.s. and B. spielmanii are recognized human pathogens in Europe, while $B$. bissettii's role in human disease remains unclear (Briciu et al., 2014). Small mammals and birds are the preferred reservoir hosts for B. burgdorferi s.s., dormice for B. spielmanii, and rodents for B. bissettii (Eisen et al., 2009).

Borrelia miyamotoi represents the only known relapsing fever group agent transmitted by Ixodes species (Potkonjak et al., 2016) with probable reservoir hosts of field mice, birds, and voles (Krause et al., 2015). B. miyamotoi has sporadic geographic distribution and has been detected in many European countries, in North America, and Asia (Crowder et al., 2014). In 2016, Kalmár et al. first reported the identification of this agent in questing ticks from central Romania (Kalmár et al., 2016). Our study confirms the existence of this pathogen in ixodid ticks from eastern Romania at a low infection rate and with limited geographic expansion.

\section{Prevalence According to Collection Sites}

Borrelia genospecies were detected at all studied areas. Infection rates in ticks from area 1 (deciduous and mixed forest vegetation) was similar to area 2 (urban area, B. burgdorferi s.l. was detected in $18.5 \%$ of ticks), thus highlighting a significant Lyme disease risk in area 2 a heavily frequented recreational hotspot. Lyme spirochetes prevalence was surprisingly higher in ticks collected from the forested but arid area 3 in southeastern Romania $(40.0 \%)$ than in ticks from the other two more northern areas, 
TABLE 3 | Co-infection between Borrelia genospecies and other tick-borne pathogens.

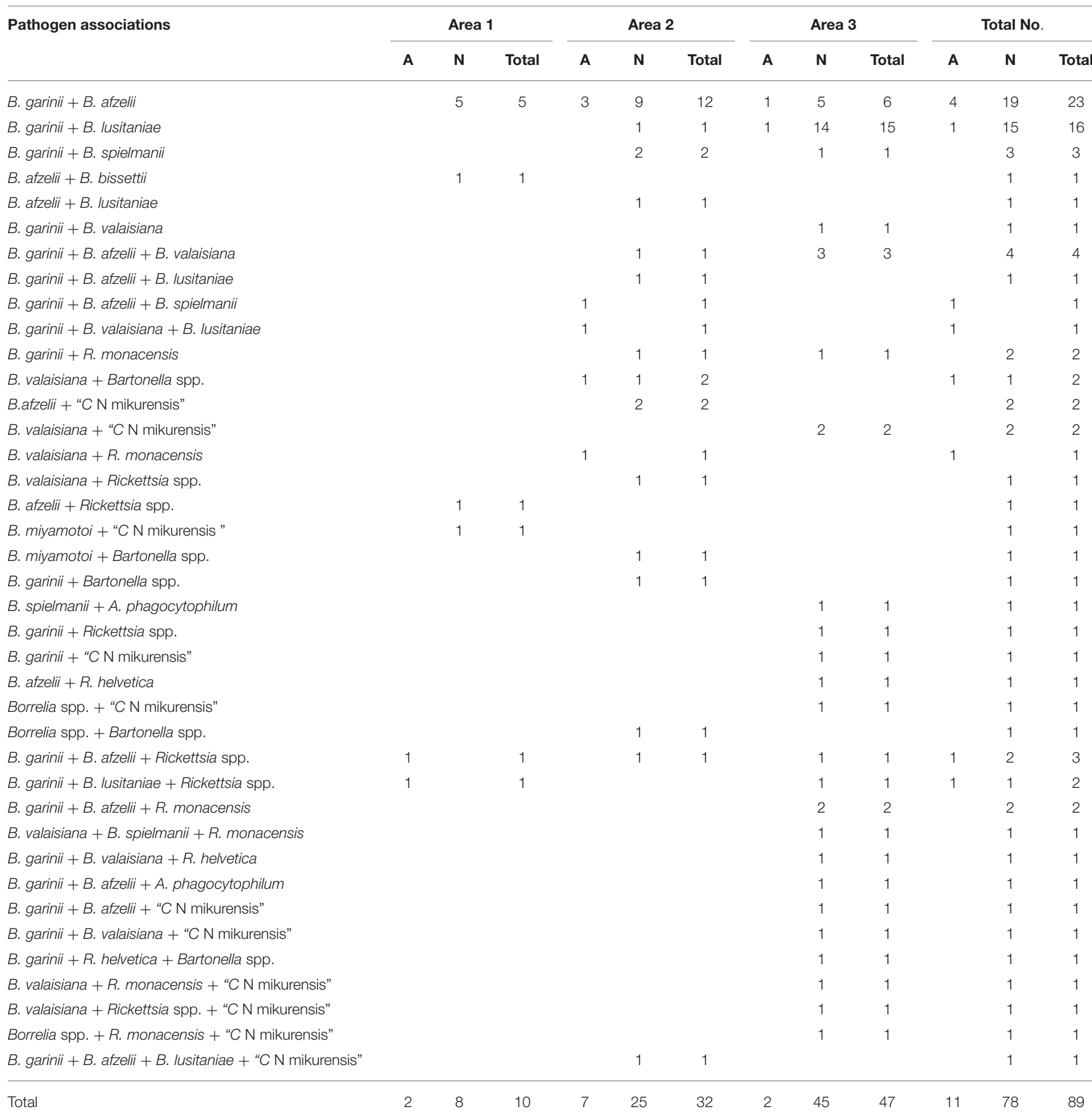

A (Adult ticks), N (Nymphs), "Candidatus Neoehrlichia mikurensis" ("C. N. mikurensis").

which both represent a more typical landscape for I. ricinus and Borrelia spirochetes.

Sampling area 3 was located in the Danube Delta Biosphere Reserve known to harbor a wide variety of mammals, migratory and resident bird species all previously described as tick hosts (Sándor et al., 2014). Thus, the combination of abundant bird fauna and the diversity of tick species might explain the high prevalence of bird-associated B. garinii and B. valaisiana.

Interestingly, the second most prevalent genospecies in questing ticks from area 3 was B. lusitaniae (11.2\%), which was also more prevalent in area 3 than the other two studied areas. Under natural conditions Borrelia lusitaniae circulates between lizards and ticks (Majláthová et al., 2008), and three lizard 
species (Podarcis muralis, Lacerta viridis, L. agilis) are designated as B. lusitaniae reservoirs (Majláthová et al., 2008). In area 3, many lizard species have been identified (L. agilis, L. viridis, $L$. trilineata, P. muralis, P. tauricus) (Cogalniceanu et al., 2013), and likely contribute to the high $B$. lusitaniae tick infection rate. Under conditions of relatively low humidity, such as in area 3, nymphs seek out their hosts from low growing vegetation, which promotes attachment to small animals during the warmer parts of the day. During these warmer daytime periods, lizards are active and mice become inactive, preferentially favoring tick attachment to lizards and subsequently, B. lusitaniae dominance (Mannelli et al., 2012).

The rodent-associated Borrelia genospecies, Borrelia afzelii, was detected in ticks from all three geographical areas with a relatively high infection rate, which could be due to the high diversity and abundance of rodent species in Romania (Mihalca et al., 2012b). In fact, studies focusing on B. burgdorferi genospecies in Romanian ticks, reported B. afzelii to be the most frequent (Coipan and Vladimirescu, 2010, 2011; Dumitrache et al., 2013; Kalmar et al., 2013; Briciu et al., 2014).

Borrelia spielmanii was only detected in areas 2 and 3, at low infection levels. This genospecies is a pathogenic spirochete transmitted by $I$. ricinus, and is associated with garden and hazel dormice (Richter et al., 2011). Dormice have a low population density in Romania (Drăgoi and Faur, 2013), which could explain the low prevalence of $B$. spielmanii in our study.

B. miyamoto $i$ was only identified at areas 1 and 2 in our study, and at a low infection rate (1.5\% in area 1 , and $1.3 \%$ in area 2$)$. No human cases of B. miyamotoi infection have been identified in Romania thus far.

\section{Prevalence in Adult Ticks and Nymph}

Usually, adult $I$. ricinus are more frequently infected with Borrelia spp. than nymphs, and as host-seeking adult ticks require two blood meals during their development, compared to one for nymphs, the likelihood of retrieving the pathogen from infected hosts is increased (Schouls et al., 1999; Geller et al., 2013; Kalmar et al., 2013; Soleng and Kjelland, 2013). Our observed adult and nymph infection rates did not follow this pattern, as I. ricinus adults were only slightly more frequently infected with Borrelia spp. than nymphs. This could be attributed to the high abundance of $I$. ricinus nymphs in study areas, which is known to positively correlate with a high rate of infected nymphs (Vennestrom et al., 2008). Additionally, adults feed on host species that are not $B$. burgdorferi s.l.-transmission competent, such as deer, resulting in a similar prevalence in adults compared to nymphs (Gray et al., 1999). Larval stages are more frequently infected with Borrelia genospecies as a result of feeding mostly on rodents, birds, and lizards, and thus acquiring the infection after a blood meal from an infected host, or by co-feeding in the vicinity of an infected nymph (van Duijvendijk et al., 2016).

\section{Tick Co-infection and Impact on Health}

In this study, we identified several pathogens co-existing within ticks. Co-infections were detected in $14.3 \%$ of adult ticks and in $17.1 \%$ of nymphs. Moreover, associations between Borrelia genospecies and between Borrelia and other tick-borne pathogens were detected in $64.5 \%$ of infected ticks. Recently, tick co-infections with different tick-borne pathogens have been more frequently reported (Reis et al., 2011; Lommano et al., 2012; Eshoo et al., 2014; Moutailler et al., 2016). This is particularly the case for I. ricinus, due to its capacity to feed on a broad variety of vertebrate species that can host multiple tick-borne pathogens (Reis et al., 2011). In our study, multiple Borrelia genospecies co-existence was identified in $9.7 \%$ of ticks, representing $37.7 \%$ of Borrelia-positive I. ricinus. Multiple Borrelia infections in individual ticks may occur via several mechanisms, such as: Superinfection of ticks with prior transovarial infection, infection with multiple pathogens via co-feeding, multiple infection after feeding on hosts positive for several Borrelia genospecies, and successive infectious blood meals (Rauter and Hartung, 2005).

In our study, the most common co-infection in individual ticks was between $B$. afzelii and B. garinii (4.3\%), as previously shown (Moutailler et al., 2016). As B. afzelii and B. garinii have different reservoir hosts (rodents and birds respectively) (Mannelli et al., 2012), infection of individual ticks with both genospecies could be the outcome of several possibilities: Immature ticks feeding on both reservoir hosts (as it is the case for positive adult ticks), infection of larvae by co-feeding (Moutailler et al., 2016), or co-infection of reservoir hosts with both $B$. afzelii and B. garinii.

The second most frequent Borrelia genospecies association was between B. garinii and B. lusitaniae. This mixed infection was predominantly detected in area 3 (Table 3 ) with many bird varieties existing as common reservoir hosts for both genospecies (Cogalniceanu et al., 2013; Sándor et al., 2014).

We detected $6.9 \%$ of ticks positive for the following coinfection associations: (i) dual co-infection with one Borrelia genospecies and another pathogen (20 ticks); (ii) co-infection of two Borrelia genospecies with another pathogen genus (12 ticks); (iii) association of a Borrelia genospecies with two other tick-borne pathogens (4 ticks); and (iv) co-infection with three Borrelia genospecies and one different pathogen genus (1 tick).

The most common tick co-infection was between Borrelia genospecies and Rickettsia monacensis, followed by the association of different Borrelia genospecies and "C. $\mathrm{N}$. mikurensis". Birds (especially blackbirds-Turdus merula) are reported as competent reservoir hosts for $R$. monacensis (Marcutan et al., 2016), a role shared with ticks. The association of "C. N. mikurensis" with B. garinii and B. valaisiana is likely due to shared reservoirs, while $R$. monacensis and $B$. afzelii co-infection could be the result of co-feeding.

Wild rodents are reservoir hosts for several Borrelia genospecies as well as " $C$. N. mikurensis" which appears to follow the same distribution pattern as the Lyme disease spirochetes (Burri et al., 2014). As “C. N. mikurensis" transovarial transmission cannot occur, ticks are likely to have been infected with both pathogens from the same host during feeding (Andersson et al., 2013). This type of multiple infection was most frequent in area 3, again likely due to reservoir host abundance. We also detected a small number of associations between Borrelia with A. phagocytophilum and Bartonella spp., adding further evidence to the hypothesis that ticks carry a large number of tick-borne pathogens in eastern Romania. 
I. ricinus nymphs represent the most high-risk stage to public health due to their small size, their marked anthropophily, their abundance, and capacity to remain attached to hosts for long durations (Vassallo et al., 2000). In addition to their crucial role as vectors of pathogens, we identified high levels of co-infection which might have important implications for human coinfection. Indeed, the multiple pathogens present in individual ticks could be co-transmitted, either resulting in a co-infection which enhances disease severity-as has been demonstrated for concurrent babesiosis and Lyme disease (Moutailler et al., 2016) — or which might evolve with atypical symptoms, resulting in diagnostic difficulties.

Our findings confirm that ticks are not only important pathogen vectors in forested areas, but also in urban situations. Worth highlighting is the risk that Lyme disease poses in areas with increased recreational activity, as we found high Borrelia genospecies infection rates in questing $I$. ricinus ticks collected from urban sites. As such, these areas require improved surveillance. We have also identified new risk areas, and have generated detailed data on the occurrence of novel and known

\section{REFERENCES}

Agoulon, A., Malandrin, L., Lepigeon, F., Venisse, M., Bonnet, S., Becker, C. A., et al. (2012). A vegetation index qualifying pasture edges is related to Ixodes ricinus density and to Babesia divergens seroprevalence in dairy cattle herds. Vet. Parasitol. 185, 101-109. doi: 10.1016/j.vetpar.2011.10.022

Andersson, M., Bartkova, S., Lindestad, O., and Raberg, L. (2013). Co-infection with 'Candidatus Neoehrlichia Mikurensis' and Borrelia afzelii in Ixodes ricinus ticks in southern Sweden. Vector Borne Zoonot. Dis. 13, 438-442. doi: 10.1089/vbz.2012.1118

Briciu, V. T., Meyer, F., Sebah, D., Tatulescu, D. F., Coroiu, G., Lupse, M., et al. (2014). Real-time PCR-based identification of Borrelia burgdorferi sensu lato species in ticks collected from humans in Romania. Ticks Tick Borne Dis. 5, 575-581. doi: 10.1016/j.ttbdis.2014.04.007

Burri, C., Schumann, O., Schumann, C., and Gern, L. (2014). Are Apodemus spp. mice and myodes glareolus reservoirs for Borrelia miyamotoi, Candidatus Neoehrlichia mikurensis, Rickettsia helvetica, R. monacensis and Anaplasma phagocytophilum? Ticks Tick Borne Dis. 5, 245-251. doi: 10.1016/j.ttbdis.2013.11.007

Chowdri, H. R., Gugliotta, J. L., Berardi, V. P., Goethert, H. K., Molloy, P. J., Sterling, S. L., et al. (2013). Borrelia miyamotoi infection presenting as human granulocytic anaplasmosis: a case report. Ann. Intern. Med. 159, 21-27. doi: 10.7326/0003-4819-159-1-201307020-00005

Clark, K. L., Leydet, B. F., and Threlkeld, C. (2014). Geographical and genospecies distribution of Borrelia burgdorferi sensu lato DNA detected in humans in the USA. J. Med. Microbiol. 63, 674-684. doi: 10.1099/jmm.0.073122-0

Cogalniceanu, D., Rozylowicz, L., Szekely, P., Samoila, C., Stanescu, F., Tudor, M., et al. (2013). Diversity and distribution of reptiles in Romania. Zookeys 341, 49-76. doi: 10.3897/zookeys.341.5502

Coipan, E. C., and Vladimirescu, A. F. (2010). First report of lyme disease spirochetes in ticks from Romania (Sibiu County). Exp. Appl. Acarol. 52, 193-197. doi: 10.1007/s10493-010-9353-0

Coipan, E. C., and Vladimirescu, A. F. (2011). Ixodes ricinus ticks (Acari: Ixodidae): vectors for Lyme disease spirochetes in Romania. Exp. Appl. Acarol. 54, 293-300. doi: 10.1007/s10493-011-9438-4

Cosson, J. F., Michelet, L., Chotte, J., Le Naour, E., Cote, M., Devillers, E., et al. (2014). Genetic characterization of the human relapsing fever spirochete Borrelia miyamotoi in vectors and animal reservoirs of Lyme disease spirochetes in France. Parasit. Vectors 7:233. doi: 10.1186/1756-3305-7-233

Crowder, C. D., Carolan, H. E., Rounds, M. A., Honig, V., Mothes, B., Haag, H., et al. (2014). Prevalence of Borrelia miyamotoi in Ixodes ticks in Europe and the United States. Emerg. Infect. Dis. 20, 1678-1682. doi: 10.3201/eid2010.131583 zoonotic pathogens, which will act as a solid foundation for further studies examining the risk of human tick-borne disease.

\section{AUTHOR CONTRIBUTIONS}

CR collected the samples, performed the experiment, and wrote the MS. IP and DP collected the samples. SM designed the studies. AM and GS discussed the results and wrote the MS. MT designed the studied, analyzed the results and wrote the MS.

\section{ACKNOWLEDGMENTS}

This work was partially funded by the INRA. We thank the Tiques et Maladies à Tiques (TMT) group of the Réseau Ecologie des Interactions Durables for stimulating discussion and support. This work was supported by the COST Action TD1303 (EurNegVec). Funding was also provided by the European Social Fund Program, Human Resources Development Operation 20072013, project no. POSDRU/159/1.5/S/132765. For AM, the work has been supported by Grant TE 298/2015.

de la Fuente, J., Estrada-Pena, A., Venzal, J. M., Kocan, K. M., and Sonenshine, D. E. (2008). Overview: ticks as vectors of pathogens that cause disease in humans and animals. Front. Biosci. 13, 6938-6946. doi: 10.2741/3200

Diuk-Wasser, M. A., Vannier, E., and Krause, P. J. (2016). Coinfection by ixodes tick-borne pathogens: ecological, epidemiological, and clinical consequences. Trends Parasitol. 32, 30-42. doi: 10.1016/j.pt.2015.09.008

Diza, E., Papa, A., Vezyri, E., Tsounis, S., Milonas, I., and Antoniadis, A. (2004). Borrelia valaisiana in cerebrospinal fluid. Emerg. Infect. Dis. 10, 1692-1693 doi: 10.3201/eid1009.030439

Drăgoi, C.-I., and Faur, M. (2013). "Monitoring dormice (Gliridae) populations as a method of evaluating the efficiency of biodiversity management tools in Grădiştea Muncelului - Cioclovina Nature Park," in 5th Symposium for Research in Protected Areas. Mittersill, 143-146.

Dubska, L., Literak, I., Kocianova, E., Taragelova, V., and Sychra, O. (2009). Differential role of passerine birds in distribution of Borrelia spirochetes, based on data from ticks collected from birds during the postbreeding migration period in Central Europe. Appl. Environ. Microbiol. 75, 596-602. doi: 10.1128/AEM.01674-08

Dumitrache, M. O., Matei, I. A., Ionica, A. M., Kalmar, Z., D’Amico, G., SikoBarabasi, S., et al. (2015). Molecular detection of Anaplasma phagocytophilum and Borrelia burgdorferi sensu lato genospecies in red foxes (Vulpes vulpes) from Romania. Parasit. Vectors 8:514. doi: 10.1186/s13071-015-1130-9

Dumitrache, M. O., Pastiu, A. I., Kalmar, Z., Mircean, V., Sandor, A. D., Gherman, C. M., et al. (2013). Northern white-breasted hedgehogs Erinaceus roumanicus as hosts for ticks infected with Borrelia burgdorferi sensu lato and Anaplasma phagocytophilum in Romania. Ticks Tick Borne Dis. 4, 214-217. doi: 10.1016/j.ttbdis.2012.11.010

Egyed, L., Elo, P., Sreter-Lancz, Z., Szell, Z., Balogh, Z., and Sreter, T. (2012). Seasonal activity and tick-borne pathogen infection rates of Ixodes ricinus ticks in Hungary. Ticks Tick Borne Dis. 3, 90-94. doi: 10.1016/j.ttbdis.2012.01.002

Eisen, L., Eisen, R. J., Mun, J., Salkeld, D. J., and Lane, R. S. (2009). Transmission cycles of Borrelia burgdorferi and B. bissettii in relation to habitat type in northwestern California. J. Vector Ecol. 34, 81-91. doi: 10.1111/j.1948-7134.2009.00010.x

Eshoo, M. W., Crowder, C. D., Carolan, H. E., Rounds, M. A., Ecker, D. J., Haag, H., et al. (2014). Broad-range survey of tick-borne pathogens in Southern Germany reveals a high prevalence of Babesia microti and a diversity of other tickborne pathogens. Vector Borne Zoonotic Dis. 14, 584-591. doi: 10.1089/vbz. 2013.1498

Gache, C. (2016). Bird fauna diversity and habitat evolution in jijioara river valley (romania). travaux du muséum national d'histoire naturelle «grigore antipa》. 582, 73-81. doi: 10.1515/travmu-2016-0008 
Geller, J., Nazarova, L., Katargina, O., and Golovljova, I. (2013). Borrelia burgdorferi sensu lato prevalence in tick populations in Estonia. Parasit. Vectors 6:202. doi: 10.1186/1756-3305-6-202

Gherman, C. M., Sandor, A. D., Kalmar, Z., Marinov, M., and Mihalca, A. D. (2012). First report of Borrelia burgdorferi sensu lato in two threatened carnivores: the marbled polecat, Vormela peregusna and the European mink, Mustela lutreola (Mammalia: Mustelidae). BMC Vet. Res. 8:137. doi: 10.1186/1746-6148-8-137

Golightly, L. M., Hirschhorn, L. R., and Weller, P. F. (1989). Fever and headache in a splenectomized woman. Rev. Infect. Dis. 11, 629-637. doi: 10.1093/clinids/11.4.629

Gray, J. S., Kirstein, F., Robertson, J. N., Stein, J., and Kahl, O. (1999), Borrelia burgdorferi sensu lato in Ixodes ricinus ticks and rodents in a recreational park in south-western Ireland. Exp. Appl. Acarol. 23, 717-729. doi: 10.1023/A:1006233700194

Grunwaldt, E., Barbour, A. G., and Benach, J. L. (1983). Simultaneous occurrence of babesiosis and Lyme disease. N. Engl. J. Med. 308, 1166. doi: 10.1056/NEJM198305123081918

Gugliotta, J. L., Goethert, H. K., Berardi, V. P., and Telford, S. R. III. (2013). Meningoencephalitis from Borrelia miyamotoi in an immunocompromised patient. N. Engl. J. Med. 368, 240-245. doi: 10.1056/NEJMoa1209039

Hall, T. A. (1999). BioEdit: a user-friendly biological sequence alignment editor and analysis program for Windows 95/98/NT. Nucleic Acids Symp. Ser. 41, 95-98.

Horowitz, H. W., Aguero-Rosenfeld, M. E., Holmgren, D., McKenna, D., Schwartz, I., Cox, M. E., et al. (2013). Lyme disease and human granulocytic anaplasmosis coinfection: impact of case definition on coinfection rates and illness severity. Clin. Infect. Dis. 56, 93-99. doi: 10.1093/cid/cis852

Hovius, J. W., de Wever, B., Sohne, M., Brouwer, M. C., Coumou, J., Wagemakers, A., et al. (2013). A case of meningoencephalitis by the relapsing fever spirochaete Borrelia miyamotoi in Europe. Lancet 382:658. doi: 10.1016/S0140-6736(13)61644-X

Ionita, M., Mitrea, I. L., Pfister, K., Hamel, D., and Silaghi, C. (2013). Molecular evidence for bacterial and protozoan pathogens in hard ticks from Romania. Vet. Parasitol. 196, 71-76. doi: 10.1016/j.vetpar.2013.01.016

Ionita, M., Silaghi, C., Mitrea, I. L., Edouard, S., Parola, P., and Pfister, K. (2016). Molecular detection of Rickettsia conorii and other zoonotic spotted fever group rickettsiae in ticks, Romania. Ticks Tick Borne Dis. 7, 150-153. doi: 10.1016/j.ttbdis.2015.10.006

Kalmar, Z., Mihalca, A. D., Dumitrache, M. O., Gherman, C. M., Magdaş, C., Mircean, V., et al. (2013). Geographical distribution and prevalence of Borrelia burgdorferi genospecies in questing Ixodes ricinus from Romania: a countrywide study. Ticks Tick Borne Dis. 4, 403-408. doi: 10.1016/j.ttbdis.2013.04.007

Kalmár, Z., Sprong, H., Mihalca, A., Gherman, C., Dumitrache, M., Coipan, E., et al. (2016). Borrelia miyamotoi and candidatus Neoehrlichia mikurensis in Ixodes ricinus ticks, Romania [letter]. Emerg. Infect. Dis. 22, 550-551. doi: $10.3201 /$ eid2203.150140

Knapp, K. L., and Rice, N. A. (2015). Human coinfection with Borrelia burgdorferi and Babesia microti in the United States. J. Parasitol. Res. 2015:587131. doi: $10.1155 / 2015 / 587131$

Krause, P. J., Fish, D., Narasimhan, S., and Barbour, A. G. (2015). Borrelia miyamotoi infection in nature and in humans. Clin. Microbiol. Infect. 21, 631-639. doi: 10.1016/j.cmi.2015.02.006

Lommano, E., Bertaiola, L., Dupasquier, C., and Gern, L. (2012). Infections and coinfections of questing Ixodes ricinus ticks by emerging zoonotic pathogens in Western Switzerland. Appl. Environ. Microbiol. 78, 4606-4612. doi: 10.1128/AEM.07961-11

Majlathova, V., Majlath, I., Derdakova, M., Vichova, B., and Pet'ko, B. (2006). Borrelia lusitaniae and green lizards (Lacerta viridis), Karst Region, Slovakia. Emerg. Infect. Dis. 12, 1895-1901. doi: 10.3201/eid1212.060784

Majláthová V., Majláth, I., Hromada, M., Tryjanowski, P., Bona, M., Antczak, M., et al. (2008). The role of the sand lizard (Lacerta agilis) in the transmission cycle of Borrelia burgdorferi sensu lato. Int. J. Med. Microbiol. 298, 161-167. doi: 10.1016/j.ijmm.2008.03.005

Mannelli, A., Bertolotti, L., Gern, L., and Gray, J. (2012). Ecology of Borrelia burgdorferi sensu lato in Europe: transmission dynamics in multi-host systems, influence of molecular processes and effects of climate change. FEMS Microbiol. Rev. 36, 837-861. doi: 10.1111/j.1574-6976.2011.00312.x
Marcutan, I. D., Kalmar, Z., Ionica, A. M., D’Amico, G., Mihalca, A. D., Cozma, V., et al. (2016). Spotted fever group rickettsiae in ticks of migratory birds in Romania. Parasit. Vectors 9, 294. doi: 10.1186/s13071-016-1565-7

Matei, I. A., Kalmar, Z., Magdas, C., Magdas, V., Toriay, H., Dumitrache, M. O., et al. (2015). Anaplasma phagocytophilum in questing Ixodes ricinus ticks from Romania. Ticks Tick Borne Dis. 6, 408-413. doi: 10.1016/j.ttbdis.2015.03.010

Michelet, L., Delannoy, S., Devillers, E., Umhang, G., Aspan, A., Juremalm, M., et al. (2014). High-throughput screening of tick-borne pathogens in Europe. Front. Cell. Infect. Microbiol. 4:103. doi: 10.3389/fcimb.2014.00103

Mihalca, A. D., Dumitrache, M. O., Sándor, A. D., Magdaş, C., Oltean, M., Györke, A., et al. (2012b). Tick parasites of rodents in Romania: host preferences, community structure and geographical distribution. Parasit. Vectors 5:266. doi: 10.1186/1756-3305-5-266

Mihalca, A. D., Gherman, C. M., Magdaş, C., Dumitrache, M. O., Györke, A., Sándor, A. D., et al. (2012a). Ixodes ricinus is the dominant questing tick in forest habitats in Romania: the results from a countrywide dragging campaign. Exp. Appl. Acarol. 58, 175-182. doi: 10.1007/s10493-012-9568-3

Moise, I., and Dumitru, S. (2012). Identifying aridization vulnerability zones in Dobrogea using medalus indices. Ann. Univ. Craiova Agric. Montanol. Cadastre Ser. XLII-1, 394-399.

Moutailler, S., Valiente Moro, C., Vaumourin, E., Michelet, L., Tran, F. H., Devillers, E., et al. (2016). Co-infection of ticks: the rule rather than the exception. PLoS Negl. Trop. Dis. 10:e0004539. doi: 10.1371/journal.pntd.0004539

Nieto, N. C., and Foley, J. E. (2009). Meta-analysis of coinfection and coexposure with Borrelia burgdorferi and Anaplasma phagocytophilum in humans, domestic animals, wildlife, and Ixodes ricinus-complex ticks. Vector Borne Zoonot. Dis. 9, 93-102. doi: 10.1089/vbz.2008.0072

Norman, A. F., Regnery, R., Jameson, P., Greene, C., and Krause, D. C. (1995). Differentiation of Bartonella-like isolates at the species level by PCR-restriction fragment length polymorphism in the citrate synthase gene. J. Clin. Microbiol. $33,1797-1803$

Pavel, I., Miron, L., Răileanu, C., Macovei, I., Tronciu, C., Acatrinei, D., et al. (2014). Seasonal dynamics of ixodid ticks in Iaşi urban area. J. Sci. Pap. Vet. Med. Univ. Agric. Sci. Vet. Med. Iaşi 57, 135-139.

Perez-Eid, C. (2007). Les tiques. Identification, Biologie, Importance Medicale et Veterinaire (In french). Paris: Editions Medicales Internationales

Potkonjak, A., Kleinerman, G., Gutiérrez, R., Savić, S., Vracar, V., Nachum-Biala, Y., et al. (2016). Occurrence of Borrelia burgdorferi sensu lato in Ixodes ricinus ticks with first identification of Borrelia miyamotoi in Vojvodina, Serbia. Vector Borne Zoonot. Dis. 16, 631-635. doi: 10.1089/vbz.2016.2008

Puchhammer-Stockl, E., Kunz, C., Mandl, C. W., and Heinz, F. X. (1995). Identification of tick-borne encephalitis virus ribonucleic acid in tick suspensions and in clinical specimens by a reverse transcription-nested polymerase chain reaction assay. Clin. Diagn. Virol. 4, 321-326.

Rauter, C., and Hartung, T. (2005). Prevalence of Borrelia burgdorferi sensu lato genospecies in Ixodes ricinus ticks in Europe: a metaanalysis. Appl. Environ. Microbiol. 71, 7203-7216. doi: 10.1128/AEM.71.11.7203-7216.2005

Regnery, R. L., Spruill, C. L., and Plikaytis, B. D. (1991). Genotypic identification of rickettsiae and estimation of intraspecies sequence divergence for portions of two rickettsial genes. J. Bacteriol. 173, 1576-1589. doi: 10.1128/jb.173.5.1576-1589.1991

Reis, C., Cote, M., Paul, R. E., and Bonnet, S. (2011). Questing ticks in suburban forest are infected by at least six tick-borne pathogens. Vector Borne Zoonot. Dis. 11, 907-916. doi: 10.1089/vbz.2010.0103

Richter, D., Schlee, D. B., and Matuschka, F. R. (2011). Reservoir competence of various rodents for the lyme disease Spirochete Borrelia spielmanii. Appl. Environ. Microbiol. 77, 3565-3570. doi: 10.1128/AEM.00022-11

Rizzoli, A., Hauffe, H., Carpi, G., Vourc, H. G., Neteler, M., and Rosa, R. (2011). Lyme borreliosis in Europe. Euro Surveill. 16:19906.

Sándor, A., Mărcuțan, D., D’Amico, G., Gherman, C., Dumitrache, M., and Mihalca, A. (2014). Do the ticks of birds at an important migratory hotspot reflect the seasonal dynamics of Ixodes ricinus at the migration initiation site? a case study in the danube delta. PLOS ONE 9:e89378. doi: 10.1371/journal.pone. 0089378

Schouls, L. M., Van De Pol, I., Rijpkema, S. G., and Schot, C. S. (1999). Detection and identification of Ehrlichia, Borrelia burgdorferi sensu lato, and Bartonella species in Dutch Ixodes ricinus ticks. J. Clin. Microbiol. 37, 2215-2222. 
Schwaiger, M., and Cassinotti, P. (2003). Development of a quantitative realtime RT-PCR assay with internal control for the laboratory detection of tick borne encephalitis virus (TBEV) RNA. J. Clin. Virol. 27, 136-145 doi: 10.1016/S1386-6532(02)00168-3

Soleng, A., and Kjelland, V. (2013). Borrelia burgdorferi sensu lato and Anaplasma phagocytophilum in Ixodes ricinus ticks in Bronnoysund in northern Norway. Ticks Tick Borne Dis. 4, 218-221. doi: 10.1016/j.ttbdis.2012. 11.006

Subramanian, G., Sekeyova, Z., Raoult, D., and Mediannikov, O. (2012). Multiple tick-associated bacteria in Ixodes ricinus from Slovakia. Ticks Tick Borne Dis. 3, 406-410. doi: 10.1016/j.ttbdis.2012.10.001

Swanson, S. J., Neitzel, D., Reed, K. D., and Belongia, E. A. (2006). Coinfections acquired from ixodes ticks. Clin. Microbiol. Rev. 19, 708-727. doi: 10.1128/CMR.00011-06

Taragel'ova, V., Koci, J., Hanincova, K., Kurtenbach, K., Derdakova, M., Ogden, N. H., et al. (2008). Blackbirds and song thrushes constitute a key reservoir of Borrelia garinii, the causative agent of borreliosis in Central Europe. Appl. Environ. Microbiol. 74, 1289-1293. doi: 10.1128/AEM.01060-07

Tijsse-Klasen, E., Sprong, H., and Pandak, N. (2013). Co-infection of Borrelia burgdorferi sensu lato and Rickettsia species in ticks and in an erythema migrans patient. Parasit. Vectors 6:347. doi: 10.1186/1756-3305-6-347

van Duijvendijk, G., Coipan, C., Wagemakers, A., Fonville, M., Ersöz, J., Oei, A., et al. (2016). Larvae of Ixodes ricinus transmit Borrelia afzelii and B. miyamotoi to vertebrate hosts. Parasit. Vectors 9:97. doi: 10.1186/s13071-016 1389-5

Vassallo, M., Paul, R., and Perez-Eid, C. (2000). Temporal distribution of the annual nymphal stock of Ixodes ricinus ticks. Exp. Appl. Acarol. 24, 941-949. doi: 10.1023/A:1010669003887

Vayssier-Taussat, M., Le Rhun, D., Buffet, J. P., Maaoui, N., Galan, M., Guivier, E., et al. (2012). Candidatus neoehrlichia mikurensis in bank voles, France. Emerg. Infect. Dis. 18, 2063-2065. doi: 10.3201/eid1812.120846

Vennestrom, J., Egholm, H., and Jensen, P. M. (2008). Occurrence of multiple infections with different Borrelia burgdorferi genospecies in Danish Ixodes ricinus nymphs. Parasitol. Int. 57, 32-37. doi: 10.1016/j.parint.2007.07.004

Conflict of Interest Statement: The authors declare that the research was conducted in the absence of any commercial or financial relationships that could be construed as a potential conflict of interest.

Copyright (c) 2017 Raileanu, Moutailler, Pavel, Porea, Mihalca, Savuta and VayssierTaussat. This is an open-access article distributed under the terms of the Creative Commons Attribution License (CC BY). The use, distribution or reproduction in other forums is permitted, provided the original author(s) or licensor are credited and that the original publication in this journal is cited, in accordance with accepted academic practice. No use, distribution or reproduction is permitted which does not comply with these terms. 